\title{
Systematically Evaluating the Effectiveness of an Information Systems Capstone Course: Implications for Practice
}

\author{
T. Grandon Gill \\ University of South Florida, \\ Tampa, FL, USA
}

ggill@coba.usf.edu

\author{
Albert D. Ritzhaupt \\ University of Florida, \\ Gainesville, FL, USA
}

aritzhaupt@gmail.com

\section{Executive Summary}

The information systems capstone experience for undergraduate majors is a topic frequently discussed in academic circles within the field. Though very little consensus exists on this topic, there are core themes that emerge in the design, development, and delivery of the undergraduate capstone courses. Our analysis of prior literature reveals four components to capstone experiences that are often used in these courses, which include 1) a focus on real-world, complex information systems design, development, and integration; 2) the use of the case method to engage students in critical thinking, problem-solving, and decision-making; 3) the use of ePortfolios to assist students in integrating knowledge across the discipline and showcasing their learning to potential employers; and 4) an emphasis with the undergraduate information systems majors interacting with seasoned professionals in the field. These dimensions were carefully considered in the implementation of a capstone course at a large research extensive university in the southeastern United States. This project was funded by a National Science Foundation (NSF) grant program.

The paper presents a novel information systems undergraduate capstone course that includes two major design themes: case pedagogy and individual projects. The course is carefully described in terms of the student learning objectives, salient features, and philosophy. Further, the course was systematically evaluated using a multi-method approach, involving five distinct data sources: the Critical Thinking Assessment Test (CAT), the Student Assessment of Learning Gains (SALG), the Student Assessment of Instruction (SAI), faculty review of mini-cases, and student and instructor reviews of final projects. These data were examined both descriptively and inferentially. Results indicate that students were generally satisfied with the course design. However, some negative comments were made. Students did not show significant increases in critical thinking skills as measured by the CAT. However, faculty review of the pre- and post-mini-case submissions shows that students had significant gains in evaluating information, creative thinking, and learn-

Material published as part of this publication, either on-line or in print, is copyrighted by the Informing Science Institute. Permission to make digital or paper copy of part or all of these works for personal or classroom use is granted without fee provided that the copies are not made or distributed for profit or commercial advantage AND that copies 1) bear this notice in full and 2) give the full citation on the first page. It is permissible to abstract these works so long as credit is given. To copy in all other cases or to republish or to post on a server or to redistribute to lists requires specific permission and payment of a fee. Contact Publisher@InformingScience.org to request redistribution permission. ing and problem-solving. Implications for practice are provided in light of the findings.

Keywords: Information systems, capstone, case pedagogy, evaluation, IS curriculum, critical thinking, education. 


\section{Introduction}

Many academic programs in the broad field of information systems offer a capstone experience for their students, and many of these faculty members share the discourse on how best to facilitate such a course for their diverse populations (Astani, 2006; Brandon, Pruett, \& Wade, 2002; Gupta, \& Wachter, 1998; Harper, Lamb, \& Buffington, 2008; Hashemi, \& Kellersberger, 2009; Janicki, Fischetti, \& Burns, 2006; Kumar, 2006; McGann, \& Cahill, 2005; Morgan, \& Aitken, 2006; Schwieger, \& Surendran, 2010; Shih, LeClair, \& Varden, 2010; Surendran, \& Schwieger, 2011; Tuttle, 2000, 2001). After more than a decade of discourse on the topic, there is still very little agreement on how best to design, develop, and deliver an information systems capstone experience for undergraduate majors. The objectives of an information systems capstone course have been described as follows: "a means for students to apply knowledge gained in previous courses and integrate those experiences in a more realistic setting, where concepts are applied simultaneously, rather than sequentially and in isolation" (Denton \& Spangler, 2001, p. 150). Such a broad mandate has necessarily led to a variety of unique approaches offered by the various academic programs in our field.

One solution, presented in the undergraduate IS 2002 model curriculum (Gorgone, Davis, Valacich, Topi, Feinstein, \& Longenecker 2003) has been to build the course around project management. An alternative approach has been to structure the course around student presentations of case studies, situation analysis reports and team projects (Brandon et al., 2002; Gupta \& Wachter, 1998). Still other courses have emphasized the use of guest speakers and student research projects (Kumar, 2006). Yet another approach is for students to develop an ePortfolio to demonstrate their competency across the curriculum (Shih et al., 2010). In most of these examples, evidence supports the view that students and faculty alike were satisfied with the course outcomes. What is less clear is the degree to which the actual learning outcomes could be demonstrated. Of particular concern is how these outcomes map to the expectations we set forth for our capstone experience.

The course that is the focus of this paper is the undergraduate capstone course for information systems majors. The course and program is situated within a College of Business at a large, research extensive state university. As of spring 2012, the first offering of the course, approximately 300 students were declared for the 2-year upper level major, meaning that course enrollment was typically between 40 and 50 students in each of the fall, spring, and summer sessions. The previous version of the capstone course - offered in a more traditional lecture-based format received relatively high student evaluations. There were concerns, however, that the full range of learning outcomes intended for a capstone course was not necessarily being achieved. These concerns motivated a redesign of that course.

Although the two core activities in the redesigned course - case pedagogy (e.g., Brandon et al., 2002; Gupta, \& Wachter, 1998; Harper et al., 2008) and student projects (e.g., Gupta, \& Wachter, 1998; Hashemi, \& Kellersberger, 2009; McGann \& Cahill, 2005 Tuttle, 2000, 2001) - have frequently been included in capstone courses, the course here described introduced many features that were quite novel. The paper begins by providing a synthesis across information systems capstone courses, then summarizes the key learning objectives of the course. The design of the course is then presented along with a philosophy, after which initial learning outcomes are described. The paper then describes a multi-method approach to systematically evaluate the course features. The paper concludes with some thoughts on the broader impacts of the project and how the project might be extended as well as implications for practice in the field of information systems at other institutions of higher education. 


\section{Relevant Literature}

Within the information systems literature, a significant disconnect exists between what we research and what we teach has been observed (Gill \& Bhattacherjee, 2009). The source of the problem seems to be that much of what we teach, particularly in undergraduate programs, is technical subjects such as programming, databases, data communications, and systems analysis and design. What we research, on the other hand, tends towards the behavioral sciences (although exceptions obviously exist). Compounding the problem is the fact that we are increasingly being asked to assess learning on core skill dimensions that do not directly relate to either activity such as problem solving, communications, collaboration, and ability to learn (Gill, 2010). Many have suggested the undergraduate capstone as a place for this assessment to occur.

The capstone experience for undergraduate information systems majors has been a topic of interest for more than a decade. As previously mentioned and as clearly illustrated in Table 1, very little agreement exists on what topics should be covered and the pedagogy for such a course. However, when examining across these various descriptions, a few pertinent themes emerge. First, across several of the course descriptions, there is an emphasis on the design, development, and implementation of real-world technology solutions for real-world clients (e.g., Gupta, \& Wachter, 1998; Hashemi, \& Kellersberger, 2009; McGann \& Cahill, 2005 Tuttle, 2000, 2001). This theme emphasizes the importance of information systems students working on authentic problems within a business domain and integrating technology with real clients to better grasp the complex process of systems analysis, design, development, and integration. Further, the emphasis on student working in teams is consistent with the belief that information system majors should be wellversed in the soft-skills of collaborating, leadership, diplomacy, and more.

A second theme to emerge from these vast course implementations is the use of the case method to engage students in complex discussions surrounding both the technology and management type decisions facing information systems professionals (e.g., Brandon et al., 2002; Harper et al., 2008). The case method is a pedagogical approach that has been widely adopted in several disciplines, including business, medicine, law, and education. In the context of information systems, we are concerned with encouraging students to engage in critical thinking, problem-solving, expression of complex ideas, synthesis and analysis, and decision-making abilities. The case method is a novel way to address these concerns by posing semi-structured and authentic problems, usually written in a way that highlights the decisions a protagonist must address. The case method is a key focus of the course design described here.

A third theme to emerge from these data is an emphasis on student portfolios (e.g., McGann \& Cahill, 2005; Shih et al., 2010), particularly ePortfolios, which involve students' representation, reflection, and revision (Ritzhaupt, Singh, Seyferth, \& Dedrick, 2008). ePortfolios are a newer approach to an old problem: helping students synthesize and integrate knowledge across their academic program and helping students showcase their knowledge, skills, and dispositions to potential employers. ePortfolios are still in their infancy in the field of information systems, but accrediting agencies like Accreditation Board for Engineering and Technology (ABET) (Brumm, Ellertson, \& Mickelson, 2003) are already exploring the utility of these tools for accreditation and student learning outcomes. We anticipate that ePortfolios will have a significant role to play in information systems programs in the near future.

A fourth and final theme to arise from the literature is an emphasis on undergraduate information systems students interacting with professionals already practicing in the field (e.g., Astani, 2006; Brandon et al., 2002; Kumar, 2006; McGann \& Cahill, 2005). Whether students are soliciting requirements from real-world clients or interviewing seasoned professionals, the contact between a student and professional is a valuable component to a capstone experience. Professional can share their experiences to help students make explicit connections between theory and practice. 
Further, this form of engagement engenders a sense of professionalism within the student body. Part of our course design emphasizes students interacting with the protagonists in the cases they read as part of the capstone course.

Table 1. Descriptions and key features of information systems capstone courses.

\begin{tabular}{|c|c|}
\hline Author(s) & Key Features and Description \\
\hline Astani (2006) & $\begin{array}{l}\text { Students were required to interview local Chief Information Officers face-to- } \\
\text { face to better understand the key issues in information technology manage- } \\
\text { ment. Students shared the findings in class. }\end{array}$ \\
\hline $\begin{array}{l}\text { Brandon, Pruett, and } \\
\text { Wade (2002) }\end{array}$ & $\begin{array}{l}\text { A combination of case pedagogy, guest speakers, and lectures to deliver con- } \\
\text { tent. Students would engage in discussions and would produce a research re- } \\
\text { port on a specific company and industry to the rest of the class. An advanced } \\
\text { graduate textbook was used. }\end{array}$ \\
\hline $\begin{array}{l}\text { Gupta, and Wachter } \\
\text { (1998) }\end{array}$ & $\begin{array}{l}\text { Lectures, targeted assignments, case studies, situation analysis report, and a } \\
\text { major team project. The course integrates several business functions and as- } \\
\text { signments to provide a comprehensive experience. }\end{array}$ \\
\hline $\begin{array}{l}\text { Harper, Lamb, and } \\
\text { Buffington (2008) }\end{array}$ & $\begin{array}{l}\text { A focus on using case pedagogy to delivery content. A comprehensive evalua- } \\
\text { tion of the case method using a valid and reliable survey instrument. The } \\
\text { course embraces discussions and case analysis. }\end{array}$ \\
\hline $\begin{array}{l}\text { Hashemi, and Kellers- } \\
\text { berger (2009) }\end{array}$ & $\begin{array}{l}\text { A focus on information systems development of a complex information sys- } \\
\text { tems spanning multiple semesters with multiple students. A focus on learning } \\
\text { several business functions. The course is an ongoing information systems de- } \\
\text { velopment project. }\end{array}$ \\
\hline $\begin{array}{l}\text { Janicki, Fischetti, and } \\
\text { Burns (2006) }\end{array}$ & $\begin{array}{l}\text { An emphasis on project management and emerging technology. The course } \\
\text { focuses on working with real-world clients to identify stakeholder needs. The } \\
\text { real-world projects come from the institution and local not-for-profits. }\end{array}$ \\
\hline Kumar (2006) & $\begin{array}{l}\text { The paper focuses on the recommendations of using a systems approach, fo- } \\
\text { cusing on student-centered activities, using multiple modes of assessment, } \\
\text { providing research opportunities, and inviting guest graduates to speak about } \\
\text { the course. }\end{array}$ \\
\hline $\begin{array}{l}\text { McGann and Cahill } \\
(2005)\end{array}$ & $\begin{array}{l}\text { A description of a comprehensive course that covers real-world client projects, } \\
\text { traditional readings and case studies, project management, individual devel- } \\
\text { opment assignments, research readings, electronic portfolios and a career } \\
\text { readiness emphasis. }\end{array}$ \\
\hline $\begin{array}{l}\text { Morgan and Aitken } \\
(2006)\end{array}$ & $\begin{array}{l}\text { A description of a capstone course for information systems majors and other } \\
\text { business majors involving the cross-functional teams and consulting experi- } \\
\text { ences. The course is organized around six modules. }\end{array}$ \\
\hline $\begin{array}{l}\text { Schwieger and Suren- } \\
\text { dran (2010) }\end{array}$ & $\begin{array}{l}\text { A description of a capstone course focusing on teamwork and developing real- } \\
\text { world technology solutions for real clients. The course emphasizes soft skills, } \\
\text { knowledge integration, and cooperative learning. }\end{array}$ \\
\hline $\begin{array}{l}\text { Shih, LeClair, and } \\
\text { Varden (2010) }\end{array}$ & $\begin{array}{l}\text { A focus on students developing an electronic portfolio (ePortfolio) to demon- } \\
\text { strate technical competence in their academic studies. The course integrates } \\
\text { across the curriculum following a pedagogical model. Students in the program } \\
\text { must complete the ePortfolio to graduate. }\end{array}$ \\
\hline $\begin{array}{l}\text { Surendran and } \\
\text { Schwieger (2011) }\end{array}$ & $\begin{array}{l}\text { Implications of the IS2010 curriculum standards for an integrated undergradu- } \\
\text { ate capstone course for information systems majors. The proposed course de- } \\
\text { sign emphasizes client-sponsored projects, enterprise system based projects, } \\
\text { instructor-directed apprenticeships in industry, and cross-discipline focused } \\
\text { independent study. }\end{array}$ \\
\hline Tuttle (2000 and 2001) & $\begin{array}{l}\text { An emphasis on a large-scale programming project involving a complex data- } \\
\text { base design and class discussions are surrounding Frederick Brooks Jr.'s "The } \\
\text { Mythical Man Month". Implications for the field are emphasized and students } \\
\text { engage in team-based challenges in class. }\end{array}$ \\
\hline
\end{tabular}


Across these discussions on undergraduate information systems capstone experiences, we can see that the field is still struggling with how best to synthesize and integrate knowledge in the various areas that constitute the information systems undergraduate major. What we can garner from these discussions is that there are several distinct ways to achieve the learning objectives of these courses ranging from traditional pedagogy to more authentic forms of engagement. In the remainder of this manuscript, we present our approach to the information systems undergraduate capstone experience by highlighting our design and systematically evaluating the effectiveness of this eclectic approach.

\section{Course Design}

Broadly speaking, an information systems program within a business school seeks to build two categories of skills in its students: technical skills and core skills. The technical skills typically involve being able to employ IT artifacts (e.g., databases, programming languages) and techniques (e.g., project development methodologies) in practical situations. The core skills, on the other hand, are those that allow the individual to contribute in a work environment and include 1) the ability to communicate effectively, 2) the ability to work effectively with people, 3 ) good problem solving skills, and 4) the ability to learn while on the job (Gill, 2010, pp. 416-417). Ironically, we find that it is these skills - rather than the technical skills that we most emphasize in our teaching - that employers most often mention when asked what they desire when they hire our students.

Taking into consideration the dimensions discussed in our literature review, the capstone course design consisted of two components: case pedagogy and individual projects. The case pedagogy involved rich cases written by faculty members in the program and highlighted protagonists that either physically or virtually attended class on the day the cases were discussed by the students. Our vision was to have the student interact with the professional (protagonists) and ask more in depth questions about the case situation. The individual project was designed to accommodate students that would either 1) enter the workforce upon completion of their degree program or 2) apply to graduate school to pursue a career of research in the field. Further, we envisioned the project being easily integrated into a student's ePortfolio for showcasing to potential employers. Because these two components focused on separate learning objectives and were largely independent of each other, they are discussed separately. Regular course evaluations were also treated as evidence of the overall effectiveness of the course, but could not be separated with respect to learning objectives.

\section{Learning Objectives}

Given that the capstone course had two goals - i) to provide students with a further opportunity for learning, and ii) to assess what students have learned in the program - it made sense to establish different objectives for the two skill types:

- Technical skills: The capstone would primarily be used as a means of assessing technical competence acquired over the course of the entire program. No specific attempt would be made to introduce specific new tools or techniques. This made sense since the information systems major already had four required courses plus a number of electives devoted primarily to technical skill development.

- Core skills: The capstone would specifically assess skill development in these areas over the duration of the course. Because such skills are notoriously difficult to measure, triangulation employing a variety of different assessment tools would be used.

In the design section, how we attempted to accomplish these objectives is further discussed. 


\section{Case Pedagogy}

To understand our position, it is useful to think of the course as an informing system involving three key stakeholders: the faculty, the students, and the practice community. As illustrated on the left side of Figure 1, the pure lecture course - admittedly a "straw man" since relatively few enlightened instructors would rely solely on such an approach - can be characterized as a series of one way information flows. The main flows are from the lecturer to the student and from the researchers (who contributed the knowledge that makes up the content of the textbook) to the instructor, since the roles of content generation and content dissemination tend not to be one and the same in such courses. Secondary informing flows occur, presumably, from practice to the researchers and, as students graduate and join practice, from students to practice.

In the traditional case method course, shown in the center, we see a substantial number of new flows arise. The informing flows in a facilitated discussion are clearly bi-directional between students and the facilitator. In addition, substantial student-to-student flows exist. The influence of practice informing the researcher/case writer also becomes much more evident for a discussion case than for the type of theory we produce, at least in the information systems field. The informing flow from case writer to facilitator still tends to be unidirectional, however, and direct links from students to practice remain secondary.

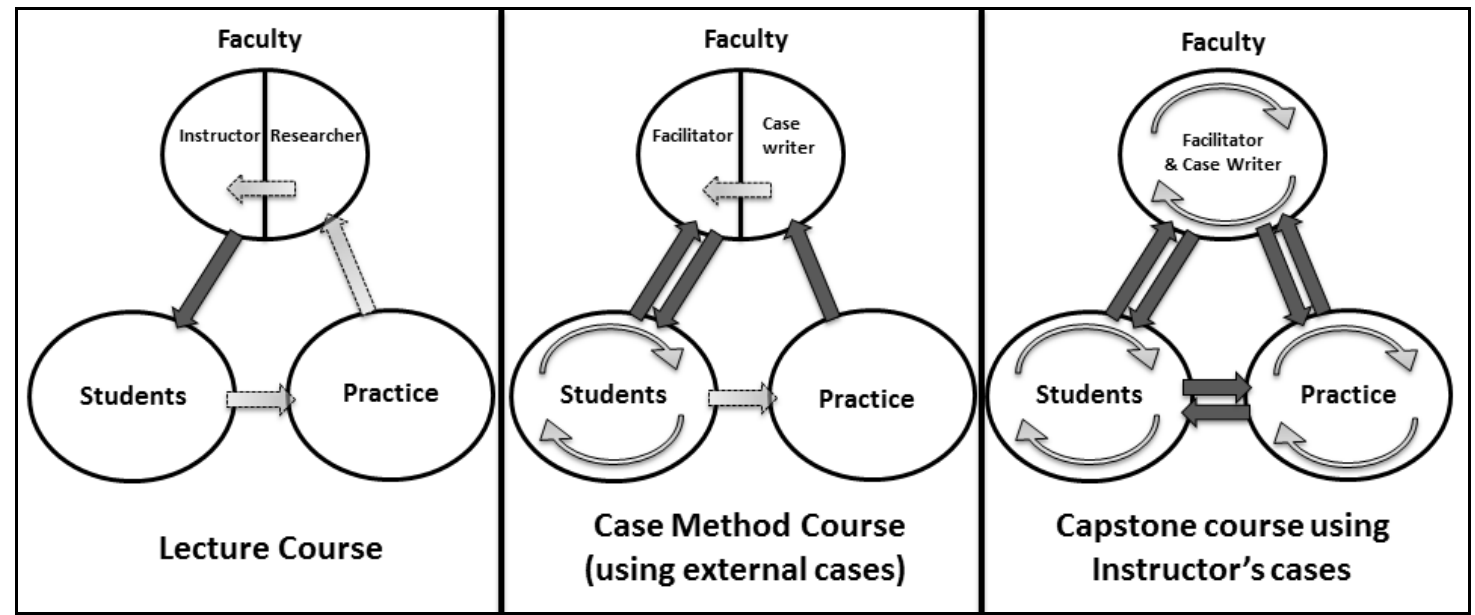

Figure 1. Three course designs expressed as informing systems.

Where the situation really gets interesting is when the facilitator develops cases for his or her own institution, and where case protagonists become participants in the discussion. In this setting - the one that we targeted for our undergraduate capstone course - informing can occur in every possible direction, at least in theory. During case development, the case writer and protagonists engage in active mutual informing. With the case protagonists in the room during the discussion, both students and practitioners can become informed. As the case writer works with other faculty members facilitating the case, each informs the other. It is even possible for practitioners to be informing each other in some venues, such as an executive program. Furthermore, in the long term, the informing activities described here could lead to the formation of lasting relationships between academics, students, and practice that could become channels for future informing. A few institutions, such as Harvard Business School, have long understood the symbiotic relationship between discussion case development, students, research, and practice; they have leveraged that knowledge to great effect. Our long term goal was to build a broader understanding of this process throughout the information systems research community (HBS, 2013). In the process, we also hoped to learn a little bit more about what case discussions accomplish in terms of learning. 


\section{Case Discussions}

Until the last two weeks of the semester - which were set aside for project poster presentations virtually all class time was utilized in discussing a single case study each week. During the first offering of the course, the class met nightly from 6:20 PM to 9:05 PM. The semester timeline is presented in Figure 2.

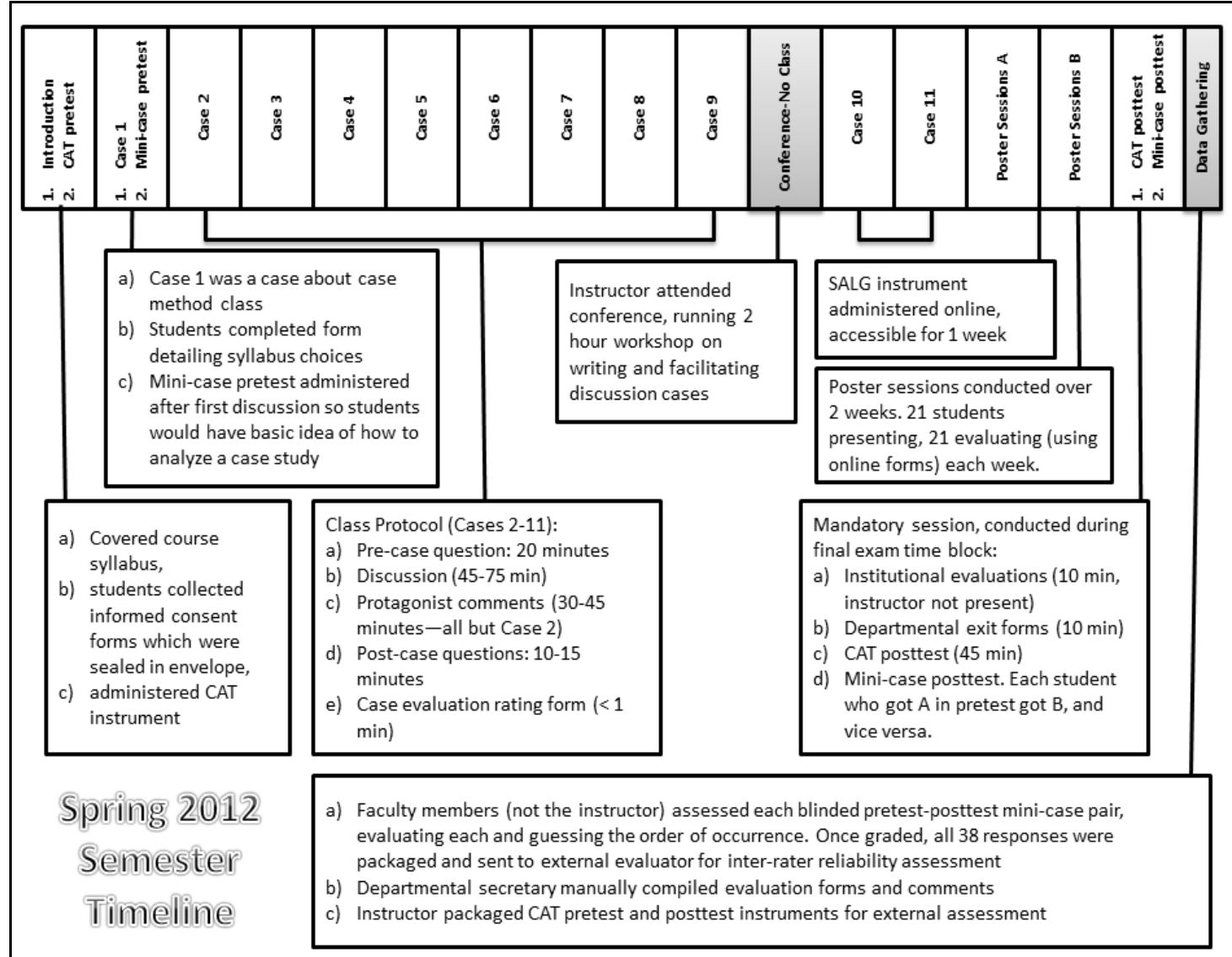

Figure 2. Activity timeline for information systems capstone course, spring semester 2012.

\section{Protocol}

We followed a consistent protocol for each class session. On a typical evening, the schedule would be as follows:

- 6:20-6:45 PM: Pre-case question. A question related to that evening's case was written on the whiteboard by the instructor. Students had 20-25 minutes to write a response and upload it to Blackboard, the institution's course management system. Laptops were made available to the 2-3 students who did not have their own.

- 6:45-7:45 PM: Case discussion. A student would be called upon to open the case without prior warning (referred to as a cold call) while the instructor wrote notes on the board. Once the opening was complete, the facilitated discussion began.

- 7:45 PM to 8:15 PM: Wrap-up. Originally, it was planned that the instructor would provide a short summary and reflections on what was covered in the discussion. In practice, the actual protagonist from the case being discussed sat in on all but one of the discus- 
sions throughout the entire semester. As a consequence, it was normally that individual who led the discussion.

- 8:15 PM to 8:30 PM: Post-case forms. Students prepared and submitted a case reflection form to Blackboard. This form always consisted of the same two questions: 1) What are the three most important things you learned from the case? and 2) How did the discussion of the case change your views? In addition, students had to fill in a brief case study rating form that was administered online.

The remainder of each class period was set aside for questions about specific projects, and students were free to leave after they had completed their post-case forms. Each week, the instructor evaluated the students' pre- and post-case submissions on a 3 point scale: $\mathrm{W}=$ weak, $\mathrm{S}=$ satisfactory, and $\mathrm{E}=$ excellent. These completed forms were also sent to the protagonist of each case.

The only major variation from the just-described protocol occurred for two cases where the protagonist was non-local, one located in Boston, Massachusetts, and one located in West Palm Beach, Florida. For these two cases, the entire class was conducted online using Elluminate, which provided a conferenced audio channel and a shared whiteboard. This venue allowed case protagonists to participate in the discussion without travelling and to share their observations with the class. The same schedule for the class period was maintained, however.

To prepare students for the case method pedagogy to be used over the course of the semester, the first case study that was discussed was a case about the design of the course itself. That case, which featured the instructor as the protagonist, presented the students with a series of decisions that included:

- Should the course contain an online component or be entirely face-to-face?

- Should progress deadlines within the class be strictly enforced or flexible?

- Should a detailed grading rubric with specific point values for each activity be established or should a more subjective approach be taken?

At the end of the case discussion - which demonstrated a surprisingly large diversity of opinion students were given the opportunity to vote anonymously using an online survey and their choices became the new course policy. Their choices were as follows:

- $60 \%$ weight for case discussion participation in final grade ( $73 \%$ percent of the class selected that participation should count for either $60 \%$ or $70 \%$; choices went as high as $70 \%$ and as low as $30 \%$ )

- Flexible grading as opposed to firm rubric (70\% voted for flexible)

- Participation balanced between oral and written forms (57\% voted for balance)

- Project grades balanced between written report and poster presentation (65\%)

- Late work accepted but with substantial penalty (59\%; $11 \%$ voted for not accepting late submissions, $30 \%$ voted for no penalty on late work)

- Classes to be held online whenever doing so made it possible for the case protagonist to attend $(57 \% ; 27 \%$ voted for no online classes and 16\% voted that online classes should be allowed only if scheduled at the beginning of the semester).

Unfortunately, regardless of whatever virtues case discussions might offer, classroom discussions alone were to help us much in understanding the success of technical component of our undergraduate program - particularly in the form of evidence that could be used for outcomes assess- 
ment for the program as a whole. For this reason, we added an individual project component. This was less driven by any literature than by our need for data: by looking at the quality of projects and distribution of project types, we hoped to learn about our effectiveness in preparing students. For this information to be useful, however, we needed to offer students considerable latitude in their choice of projects.

\section{Final Projects}

The decision was made that each project be an individual, rather than team, effort. There were two compelling reasons for this choice. First, our intention was to use the distribution of projects as an indicator of where our technical focus was strongest and weakest. The second was our interest in using the quality of these projects as a basis for evaluating the overall performance of our major for purposes of accreditation and state-mandated programs. These agencies invariably looked for evidence that documented individual work. It was also felt that the program already had so much group work that additional team-related activities in the capstone were not mandatory. The purpose of the project is to demonstrate the technological and research skill that students have acquired over the course of the information systems major. The project was intended to involve substantial complexity but students were given substantial freedom in project type. Instructions provided in the course syllabus were as follows:

- A programming project: A stand-alone or web-based project that involves substantial coding in a programming language such as $\mathrm{C} \#$, VB, or Java. Mobile apps or a web-based project involving PHP or some other environment (ASP, Ruby-on-Rails) were also allowed.

- A database project: A project built around designing an SQL-based database (as well as related forms, queries, and reports) for a particular business situation. Real-world or test data was used.

- An analysis and design project: A project built around designing a system or application. Appropriate diagrams (entity-relationship diagrams, unified modeling language notation) were prepared, along with form layouts, business process diagrams, and project plans.

- A real-world web site: For pure web site projects, a real-world client was required. Such a client may have been identified by the student or, from time to time, supplied by the instructor. A thorough needs analysis and approach to determining the effectiveness of such a site was required for this category of project.

- A real-world case study: Students working in business or facing complex career decisions may choose to develop a case study that is intended for use in subsequent offerings of the course. These projects had to be developed in close collaboration with the instructor and necessarily demanded a very high standard of quality.

- A research white paper: An in-depth research paper-20 pages in length or more-that explores a particular technology, such as WiMax, or information systems issue, such as outsourcing. Safe Assignment was used to ensure that the work is original. Students should have a substantial number of sources and should cite them.

Throughout the semester, the instructor met with students after class to discuss the progress of their project proposals and their final projects. Early in the semester, students submitted a project proposal. The instructor provided comments on these proposals and approved them when they were in a form that made sense. Students were not allowed to begin their projects until they were approved by the instructor. A month or so before the end of the semester, students were required to submit a draft of their project that included all their work to that point. The instructor graded and commented on the draft. Students were encouraged to incorporate these comments into their final submissions. 
Each student prepared a PowerPoint presentation describing his or her project. The individual slides were posted on a "science fair" style board. For database, programming and other "runnable" projects, computer versions were generally demonstrated as well. Half the class presented during each poster session, and the other half (and the instructor) acted as "judges" using a rotation scheme akin to "speed dating". Half the students - the ones not presenting - evaluated each student's poster during the poster session using a formal rubric provided by the instructor. Six to ten of the best poster presentations were selected for presentation at the meeting of the Department Executive Advisory Board. This board consists of over 20 of the top information technology executives in the region. Projects were graded based upon the difficulty of the project and the quality of its components. Presentation peer evaluations were included in this assessment. Figure 3 illustrates the layout for the poster sessions.

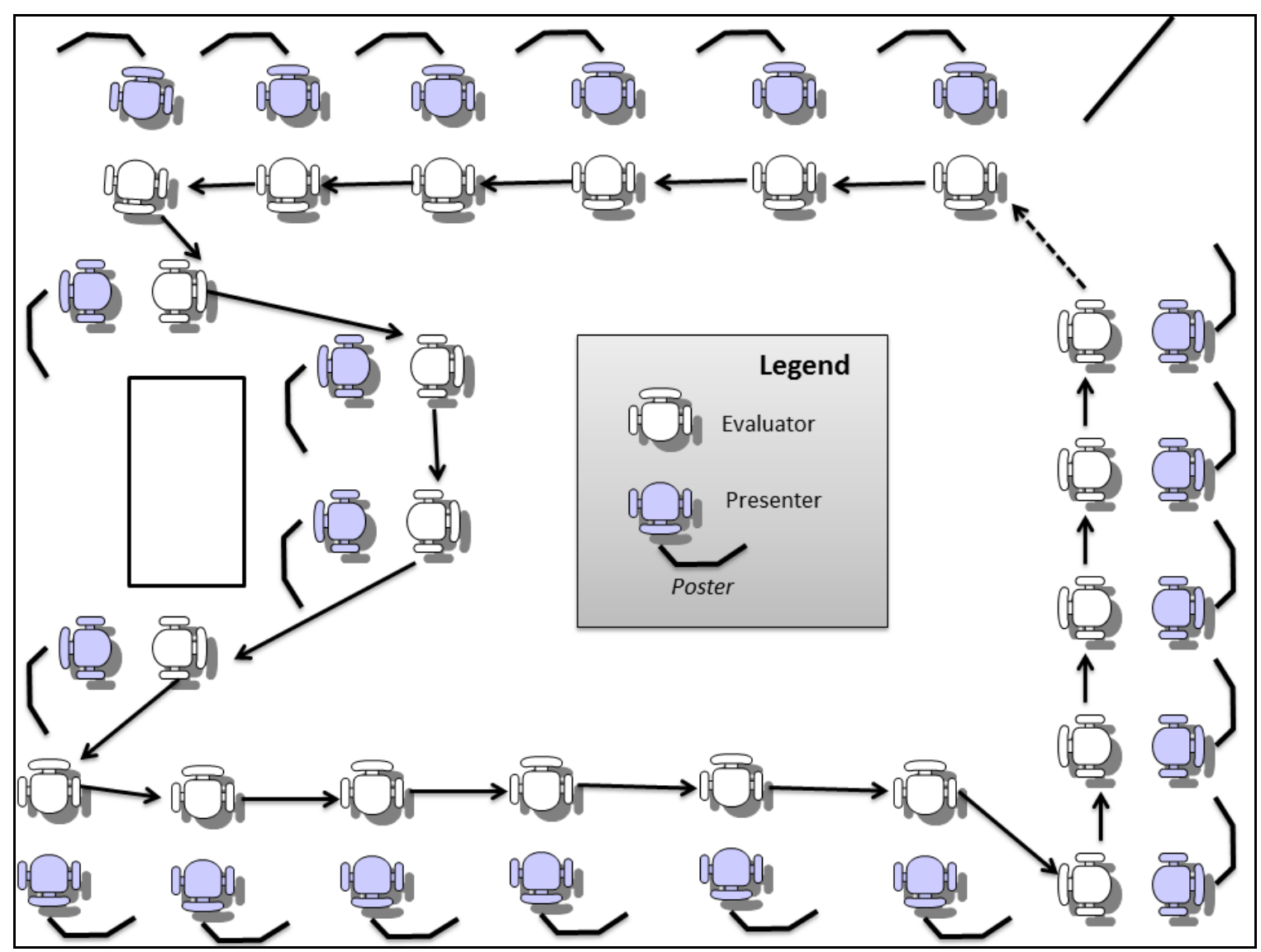

Figure 3. Poster Presentation Classroom Layout.

Students responsible for the top eight posters were invited to the spring 2012 meeting of the department's Executive Advisory Board (EAB). This board, consisting of roughly 20 of the top IT executives in the university's service area, then acted as judges during a 1 hour session scheduled during the board meeting. This offered the students considerable visibility while, at the same time, providing the basis for an external evaluation of our program as a whole (or, at least, the top quintile of our program). The three strongest student presentations were then awarded cash prizes. 


\section{Method of Evaluation}

This paper relies on several data sources using a multi-method approach (Bryman, 2006) for the evaluation of this eclectic course. The evaluation system included several data sources to triangulate findings, indulging faculty mini-case evaluations, the Critical Thinking Assessment Test (CAT), the Student Assessment of Learning Gains (SALG), the Student Assessment of Instruction (SAI), and student and instructor reviews of final projects. This paper evaluates the Spring 2012 offering of the course, which included 42 information systems undergraduate students. Figure 2, presented earlier, presents a timeline of the data collection procedures for this evaluation.

\section{Student Assessment of Instruction}

We used the final course evaluations completed by students at the end of the semester to evaluate the student perception of the course. Specifically, the instrument is titled the Student Assessment of Instruction (SAI). This instrument is used university-wide for all courses and consists of eight items and a general open-ended item for free-form responses. The instrument has been shown to demonstrate both validity and reliability across disciplines and course levels (e.g., undergraduate versus graduate). These data were analyzed descriptively.

\section{Faculty Mini-Case Evaluations}

Each student was randomly assigned to analyze one of the two cases on the first day, and the other on the last day. Faculty members in information systems (who were not the instructor) then assessed both responses on a series of dimensions and were required to guess the order in which the student had performed the analyses (first or last). In addition, an external evaluator at a different university performed the same rating and guessing task on all of the responses, allowing interrater reliability to be established. The correlations between the faculty members rating and the external evaluator ratings follow: evaluating information was .23, for creative thinking was .14, for learning and problem-solving was .39 , for communication was .06 , and overall was .30 . We report the faculty member assessments within this manuscript. These data were analyzed both descriptively and inferentially. We included an example mini-case in the Appendix to give the reader an understanding of the tasks involved as well as the structure of the cases in general.

\section{Critical Thinking Assessment Test (CAT)}

A NSF-funded instrument intended to measure overall changes in critical thinking and its individual components was used in this evaluation. These four components were 1) Evaluating information, 2) Creative thinking, 3) Learning and problem solving, and 4) Communication (see http://www.tntech.edu/cat/home/). Each student completed the same instrument before and after the course, after which the results were sent to external graders trained by the institution that developed the instrument. The CAT instrument has been shown to demonstrate both validity and reliability under several different conditions (Stein, Haynes, Redding, Ennis, \& Cecil, 2007; Stein, Haynes, Redding, Harris, Tylka, \& Lisic, 2010). The results are illustrated to gauge student gains in each of the dimensions listed. A random sample of 20 CATs was analyzed for this evaluation program. These data were analyzed descriptively and inferentially.

\section{Student Assessment of Learning Gains}

With a week left in the semester, students also were asked to fill out an online form modeled after the Student Assessment of Learning Gains (SALG; http://www.salgsite.org/) instrument, which rates elements of a course based upon how helpful to learning they are perceived to be. This instrument has been used in the information systems context in other studies and has been shown to 
have an internally consistent structure (Ritzhaupt \& Gill, 2008). The SALG was administered via an online survey. These data were analyzed descriptively.

\section{Student and Instructor Final Project Evaluation}

Both the instructor of the course and the students within the course participated in an evaluation of the final student projects using well-understood criteria. These criteria were communicated to students prior to the evaluation, and students were informed that their peer evaluation would be used to calculate the final grades in the course. These criteria included difficulty, quality, and presentation. We also counted the distribution of final projects types in each category as listed in the descriptions above. The peer and instructor evaluations were conducted at the end of the semester after the final projects had been presented at the poster session. These data were analyzed descriptively.

\section{Evaluation Results}

\section{Student Assessment of Instruction}

Although not necessarily measuring learning, student evaluation results are critical to instructors for two reasons: 1) they provide a consistent measure of student reaction that can be compared from semester to semester, and 2) they are often used as the principal basis for assessing a faculty members teaching performance. The summary evaluation results for Spring 2012 are presented in Table 2 and Table 3. The quantitative results were substantially higher than departmental averages for undergraduate courses. Specifically, the Fall 2011 semester overall average of all 8-items across undergraduate courses taught by the instructor's department was 4.24 , while the last column of Table 1 averaged 4.51.

Table 2. Results of institution's 8 item student evaluation of instruction.

\begin{tabular}{|c|c|c|c|c|c|c|}
\hline Item & $\begin{array}{l}\text { Excellent } \\
\quad(5)\end{array}$ & $\begin{array}{c}\text { Very } \\
\text { Good } \\
(4)\end{array}$ & $\begin{array}{c}\text { Good } \\
(3)\end{array}$ & $\begin{array}{l}\text { Fair } \\
\text { (2) }\end{array}$ & $\begin{array}{l}\text { Poor } \\
\text { (1) }\end{array}$ & Average \\
\hline $\begin{array}{l}\text { 1. Description of course objec- } \\
\text { tives and assignments }\end{array}$ & $26(65 \%)$ & $10(25 \%)$ & $4(10 \%)$ & $0(0 \%)$ & $0(0 \%)$ & 4.55 \\
\hline $\begin{array}{l}\text { 2. Communication of ideas and } \\
\text { information }\end{array}$ & $24(57 \%)$ & $13(31 \%)$ & $5(12 \%)$ & $0(0 \%)$ & $0(0 \%)$ & 4.45 \\
\hline $\begin{array}{l}\text { 3. Expression of expectations for } \\
\text { performance in this class }\end{array}$ & $28(70 \%)$ & $4(10 \%)$ & $6(15 \%)$ & $2(5 \%)$ & $0(0 \%)$ & 4.45 \\
\hline $\begin{array}{l}\text { 4. Availability to assist students } \\
\text { in or out of class }\end{array}$ & $26(63 \%)$ & $10(24 \%)$ & $3(7 \%)$ & $1(2 \%)$ & $1(2 \%)$ & 4.44 \\
\hline $\begin{array}{l}\text { 5. Respect and concern for stu- } \\
\text { dents }\end{array}$ & $31(78 \%)$ & $6(15 \%)$ & $1(3 \%)$ & $2(5 \%)$ & $0(0 \%)$ & 4.65 \\
\hline $\begin{array}{l}\text { 6. Stimulation of interest in the } \\
\text { class }\end{array}$ & $24(60 \%)$ & $12(30 \%)$ & $2(5 \%)$ & $2(5 \%)$ & $0(0 \%)$ & 4.45 \\
\hline 7. Facilitation of learning & $23(61 \%)$ & $11(29 \%)$ & $4(11 \%)$ & $0(0 \%)$ & $0(0 \%)$ & 4.50 \\
\hline $\begin{array}{l}\text { 8. Overall assessment of instruc- } \\
\text { tor }\end{array}$ & $27(68 \%)$ & $9(23 \%)$ & $3(8 \%)$ & $1(3 \%)$ & $0(0 \%)$ & 4.55 \\
\hline
\end{tabular}

Student comments reflected a similarly positive attitude towards the course, with some qualifications. Of 21 comments (about 50\% of the class), 16 were almost entirely positive in tone, two were negative and three could best be characterized as mixed. The five most positive and all the negative and mixed comments (as judged by the instructor) are presented in Table 3. A consistent theme in nearly all the negative comments was the repetitive nature of the poster presentations, 
since each student had to present his or her work 21 times. This theme also appeared in some positive comments, framed as a suggestion to have students present once to the entire class.

Table 3. Five most positive and least positive student comments on course evaluations.

\section{Most Positive Least Positive}

\begin{tabular}{|l|l|}
\hline The class was a major refresher compared to the & Negative: Wasted money on a class to learn nothing
\end{tabular}

other courses. The instructor treated all students as - case studies which taught me nothing. Asked for

adults rather than children. His teaching method help with project and he couldn't help. I taught mywas very "rebellious" for this school. Allowing the self everything. I learned from this class why did I students to act out and show what they know versus pay someone for education.

lectures and exams made the class a great experience.

Really enjoyed the class study structure of the class. The case studies help me to better analyze business problems and situations while learning more about current ISM technology.

Overall this was an interesting course. Some of the tools I learned will be put into action in my future job positions. This type of class structure should be in all business majors.

Great class! I loved having the discussions about the cases because it gave me the opportunity to learn more about technology in our society $\&$ how to manage it well \& to take it to the next level to help people. I loved how the cases were from different industries. I think an area of improvement would be to either have a small class or a better room that can facilitate more interactive conversations.

Negative: The cases were too long and take a long time out of class to prepare. Also the descriptions for the project were a little vague, needs more structure as a whole.

Mixed: Presentation of cases to half of the class, 21 students to be exact was a lot. Needs some adjustment. Case preparation is a lot - also maybe cut down on the number of cases.

Mixed: I enjoyed the format of the class, it was very unconventional. Most of the cases were interesting and related to the MIS field. There were quite a few spelling and grammar errors throughout them. The Project section of the class gave me time to explore my own interests in the field and to learn more about a specific topic. The poster session however was not helpful to our learning, just to everyone losing their voice. Perhaps just presenting the projects to the entire class at once would be a better way to handle the presentations.

This was my favorite class. I felt like I learned more in this class than I have in the last two years.

Mixed: I did not enjoy the poster session. I did not like having to present 20 times. I would have rather presented once. I did enjoy the guests and case studies.

\section{Student Assessment of Learning Gains}

With a week left in the semester, students also were asked to fill out an online form modeled after the Student Assessment of Learning Gains (SALG) instrument, which rates elements of a course based upon how helpful to learning they are perceived to be. These results are presented in Table 4. While it is difficult to make general statements about how such results should be interpreted, in mathematics and the sciences scores of three or better are considered positive, and averages approaching four are viewed as highly favorable (FLAG, 2012; Seymour, Weise, Hunter, \& Daffinrud, 2000). In a SALG survey of a programming course within an MIS program (Ritzhaupt \& Gill, 2008, p. 290), a list of 20 instructional items yielded a mean of 3.61, a median of 3.47 and a maximum of 4.42. These were viewed as positive outcomes.

Broadly speaking, these results suggest that students perceived the cases to be particularly valuable in the context of understanding information systems and "real world" issues, while projects and cases were roughly equivalent with respect to core skills. Projects had a distinct edge with respect to technical skills, not surprisingly. More surprisingly, perhaps, they also showed a slight edge in the area of communications skills - almost certainly a result of the poster sessions. Interestingly, poster sessions were rated among the least helpful of the innovations, although the divergence in opinion was substantial (consistent with student comments). This finding comes with 
an important caveat, however, since the large range of difficulty and quality in projects virtually guaranteed that some people would be uncomfortable presenting what they had submitted. The low online session rating was probably the result of both technical issues and the fact that they were being compared with the highly successful face-to-face classes involving protagonists. The perceived helpfulness of both local companies and protagonists sitting in were both very high.

Table 4. Results of SALG survey (35 responses out of 42 students; $83 \%$ response rate).

\begin{tabular}{|c|c|c|c|c|c|c|}
\hline Item & 1 & 2 & 3 & 4 & 5 & Average \\
\hline \multicolumn{7}{|c|}{$\begin{array}{l}\text { How helpful were the case studies and discussions in the following areas } \\
\text { 1=Not at all helpful, } 2=\mathrm{A} \text { little, } 3=\text { Somewhat, } 4=\mathrm{A} \text { lot, } 5=\mathrm{A} \text { great deal }\end{array}$} \\
\hline Understanding MIS concepts & $0 \%$ & $5.71 \%$ & $11.43 \%$ & $37.14 \%$ & $45.71 \%$ & 4.23 \\
\hline $\begin{array}{l}\text { Understanding relationships between } \\
\text { concepts }\end{array}$ & $0 \%$ & $2.86 \%$ & $8.57 \%$ & $48.57 \%$ & $40 \%$ & 4.26 \\
\hline Understanding real world issues & $0 \%$ & $0 \%$ & $0 \%$ & $22.86 \%$ & $77.14 \%$ & 4.77 \\
\hline Improving my problem solving & $0 \%$ & $0 \%$ & $25.71 \%$ & $37.14 \%$ & $37.14 \%$ & 4.11 \\
\hline Improving my creativity & $0 \%$ & $0 \%$ & $42.86 \%$ & $14.29 \%$ & $42.86 \%$ & 4.00 \\
\hline Improving my analytical ability & $0 \%$ & $2.86 \%$ & $8.57 \%$ & $42.86 \%$ & $45.71 \%$ & 4.31 \\
\hline Improving my technical skills & $0 \%$ & $25.71 \%$ & $25.71 \%$ & $22.86 \%$ & $25.71 \%$ & 3.49 \\
\hline Improving my communications skills & $0 \%$ & $11.43 \%$ & $37.14 \%$ & $25.71 \%$ & $25.71 \%$ & 3.66 \\
\hline \multicolumn{7}{|c|}{$\begin{array}{l}\text { How helpful were the projects and poster presentations in the following areas } \\
\text { 1=Not at all helpful, } 2=\mathrm{A} \text { little, } 3=\text { Somewhat, } 4=\mathrm{A} \text { lot, } 5=\mathrm{A} \text { great deal }\end{array}$} \\
\hline Understanding MIS concepts & $5.71 \%$ & $5.71 \%$ & $20 \%$ & $31.43 \%$ & $37.14 \%$ & 3.89 \\
\hline $\begin{array}{l}\text { Understanding relationships between } \\
\text { concepts }\end{array}$ & $2.86 \%$ & $17.14 \%$ & $11.43 \%$ & $34.29 \%$ & $34.29 \%$ & 3.80 \\
\hline Understanding real world issues & $2.86 \%$ & $8.57 \%$ & $31.43 \%$ & $14.29 \%$ & $42.86 \%$ & 3.86 \\
\hline Improving my problem solving & $2.86 \%$ & $8.57 \%$ & $22.86 \%$ & $20 \%$ & $45.71 \%$ & 3.97 \\
\hline Improving my creativity & $2.94 \%$ & $11.76 \%$ & $8.82 \%$ & $26.47 \%$ & $50 \%$ & 4.09 \\
\hline Improving my analytical ability & $2.86 \%$ & $5.71 \%$ & $17.14 \%$ & $28.57 \%$ & $45.71 \%$ & 4.09 \\
\hline Improving my technical skills & $2.86 \%$ & $14.29 \%$ & $8.57 \%$ & $20 \%$ & $54.29 \%$ & 4.09 \\
\hline Improving my communications skills & $5.88 \%$ & $8.82 \%$ & $11.76 \%$ & $44.12 \%$ & $29.41 \%$ & 3.82 \\
\hline \multicolumn{7}{|c|}{$\begin{array}{l}\text { How helpful were the following innovations introduced in the course } \\
1=\text { Not at all helpful, } 2=\text { A little, } 3=\text { Somewhat, } 4=A \text { lot, } 5=\text { A great deal }\end{array}$} \\
\hline Pre and post case surveys & $5.71 \%$ & $14.29 \%$ & $20 \%$ & $31.43 \%$ & $28.57 \%$ & 3.63 \\
\hline Local companies as cases & $0 \%$ & $2.86 \%$ & $5.71 \%$ & $25.71 \%$ & $65.71 \%$ & 4.54 \\
\hline Protagonists sitting in as guests & $0 \%$ & $0 \%$ & $5.71 \%$ & $22.86 \%$ & $71.43 \%$ & 4.66 \\
\hline Online sessions with protagonists & $17.14 \%$ & $14.29 \%$ & $31.43 \%$ & $20 \%$ & $17.14 \%$ & 3.06 \\
\hline Flexibility in types of project allowed & $2.86 \%$ & $0 \%$ & $8.57 \%$ & $11.43 \%$ & $77.14 \%$ & 4.60 \\
\hline Science fair poster sessions & $14.29 \%$ & $17.14 \%$ & $20 \%$ & $17.14 \%$ & $31.43 \%$ & 3.34 \\
\hline
\end{tabular}

One survey result was entirely unambiguous. The first survey question asked students if they preferred a) the new structure or b) reverting back to the previous lecture-intensive structure. Thirtytwo out of 35 respondents $(91 \%)$ indicated that they preferred the reinvented format. This finding was particularly important since the course had been entirely re-designed.

\section{Mini-Case Results}

A total of 38 mini-case pairs were evaluated by four NSF grant participants (co-PIs or senior personnel) from the project team. Prior to the assessment, the instructor had grouped the two responses for each student in the same order (A-case then B-case). The evaluators then rated each response ( 2 per student) using the same four criteria employed by the CAT instrument on a one to five scale. The instructor then took the evaluators' forms and determined if each rated case was a before or after rating, based upon when the student took the test. These ratings are summarized in Table 5. All differences between post- and pre-test averages were positive. With the exception of 
Communication, all differences were also significant at the .05 level, with Creative Thinking and Overall differences significant at $p<.01$.

Table 5. Results of mini-case ratings for before and after course (1=Poor to 5=Excellent).

\begin{tabular}{|l|c|c|c|}
\hline \multicolumn{1}{|c|}{ Item } & $\begin{array}{c}\text { Average before } \\
\text { course }\end{array}$ & $\begin{array}{c}\text { Average after } \\
\text { course }\end{array}$ & $\begin{array}{c}\text { p-value for } \\
\text { T-Test }\end{array}$ \\
\hline 1) Evaluating information & 2.92 & 3.45 & .018 \\
\hline 2) Creative thinking & 2.63 & 3.19 & .003 \\
\hline 3) Learning and problem solving & 2.82 & 3.26 & .045 \\
\hline 4) Communication & 2.97 & 3.34 & .056 \\
\hline 5) Overall & 2.79 & 3.43 & .004 \\
\hline
\end{tabular}

The second approach to assessing learning was to ask the rater - for each pair - to guess which analysis appeared to have been done after the course. Of the 38 pairs analyzed, the evaluators guessed correctly overall 27 times (71\%). Because each evaluator filled out only 9 or 10 forms, the scores for individual evaluators were computed. These differed widely: 50\%, 89\%, 70\% and $78 \%$. The overall result proved to be slightly below our targeted value of $80 \%$, but still important.

One factor that clearly influenced the evaluation results was the nature of the mini-case being evaluated. The A-case described a situation where a development project was falling behind schedule without providing a list of clear alternative actions. For this case, the average difference between before and after overall scores was relatively small (0.23). As a result, the most common error was for raters to misjudge when A was the second case (error rate: 7 out of 19). The B-case centered on a website design problem offering the student a choice between a clear set of technology alternatives. Here the before and after difference was over three times larger $(0.78)$ and raters misjudged far less often (error rate: 4 out of 19). The distinction here is important, because all the actual case studies developed for the course included a list of options by design - a decision made to tailor the cases to undergraduates.

\section{Student Project Results}

Two results with respect to student projects of particular interest were 1) the distribution of project types (and relative quality in each category), and 2) how instructor perceptions of project difficulty and quality differed from the ratings compiled by students (half of whom rated each project poster session). The summary results are presented in Table 6.

The correlation between the instructor's evaluations and student evaluation averages for each project was quite reasonable - .68 for difficulty, .52 for quality, and .56 for presentation. Generally speaking, student scores between items were much more highly correlated (e.g., .81, .82, and .60 for difficulty-quality, quality-presentation and presentation-difficulty) than the instructor's (.50, .40 , and .10). The top 8 projects were invited to present at the department's EAB meeting; 6 students were able to attend in person. These posters were scored by executives using the same form used by students. The executive average overall rating was 3.67, contrasted with average student ratings of 4.65 for the same set of 6 projects. The EAB's self-reported perception of the projects was, nevertheless, highly positive.

Table 6. Project distributions, instructor ratings and student ratings.

\begin{tabular}{|l|l|c|c|c|c|c|c|}
\hline & $\#$ & $\begin{array}{c}\text { Instructor } \\
\text { Difficulty }\end{array}$ & $\begin{array}{c}\text { Student } \\
\text { Difficulty }\end{array}$ & $\begin{array}{c}\text { Instructor } \\
\text { Quality }\end{array}$ & $\begin{array}{c}\text { Student } \\
\text { Quality }\end{array}$ & $\begin{array}{c}\text { Instructor } \\
\text { Presentation }\end{array}$ & $\begin{array}{c}\text { Student } \\
\text { Presentation }\end{array}$ \\
\hline Programming & 5 & 4.80 & 4.87 & 4.20 & 4.62 & 3.60 & 4.39 \\
\hline Database & 14 & 3.79 & 4.15 & 4.36 & 4.36 & 4.43 & 4.32 \\
\hline Systems A\&D & 1 & 3.00 & 4.20 & 3.00 & 4.40 & 4.00 & 4.55 \\
\hline Website & 8 & 3.63 & 4.12 & 4.38 & 4.53 & 4.63 & 4.33 \\
\hline Case study & 2 & 3.50 & 3.23 & 4.00 & 3.60 & 4.00 & 3.75 \\
\hline Research & 12 & 2.92 & 3.79 & 3.67 & 4.11 & 4.00 & 4.08 \\
\hline
\end{tabular}


With respect to the distribution of projects, the large number of database entries was consistent with the department's focus on business intelligence and the substantial number of course offerings in the database area (including data warehousing and data mining topics). The distribution also suggested that programming offerings might need to be strengthened and that demand existed for a course that dealt with the construction of websites and the use of open source code. Also important to note was the high distribution of research projects submitted. This suggests that several of the students might pursue advanced study in the field. However, it might also be indicative of the fact that the students were attending a research extensive university.

\section{Critical Thinking Assessment Test (CAT)}

Although aggregate scores increased on the Critical Thinking Assessment Test (CAT) from pretest to post-test, the change in the scores was statistically insignificant. The scores broken down by question type can be gleaned in Table 7. In fact, in some areas, we actually observed decreases from pre-test to post-test. For instance, we observed a decrease in a students' ability to identify additional information needed to evaluate a hypothesis, determine whether an invited inference is supported by specific information, separate relevant from irrelevant information when solving a real-world problem, provide alternative explanations for spurious associations, and identify and explain the best solution for a real-world problem using relevant information. This was a disappointment in that the case method is intended to refine a student's ability to use information and make sound judgments. The only area that showed a statistically significant increase was the students' ability to summarize the pattern of results in a graph without making inappropriate inferences. We see this as a spurious finding since the case studies themselves did not explicitly focus on a student's ability to interpret complex information from a graph.

Table 7. Pre and post means on the CAT by question type.

\begin{tabular}{|l|c|c|}
\hline & \multicolumn{2}{c|}{$\begin{array}{c}\text { Score } \\
\text { Skill Assessed by CAT Question }\end{array}$} \\
\cline { 2 - 3 } & $\begin{array}{c}\text { Pre } \\
\text { Mean }\end{array}$ & $\begin{array}{c}\text { Post } \\
\text { Mean }\end{array}$ \\
\hline Summarize the pattern of results in a graph without making inappropriate inferences. & 0.60 & $0.95^{*}$ \\
\hline Evaluate how strongly correlational-type data supports a hypothesis. & 1.25 & 1.50 \\
\hline Provide alternative explanations for a pattern of results that has many possible causes. & 0.80 & 0.65 \\
\hline Identify additional information needed to evaluate a hypothesis. & 0.65 & 0.60 \\
\hline Evaluate whether spurious information strongly supports a hypothesis. & 0.85 & 0.80 \\
\hline Provide alternative explanations for spurious associations. & 1.60 & 1.57 \\
\hline Identify additional information needed to evaluate a hypothesis. & 0.25 & 0.35 \\
\hline Determine whether an invited inference is supported by specific information. & 0.90 & 0.75 \\
\hline Provide relevant alternative interpretations for a specific set of results. & 1.10 & 0.95 \\
\hline Separate relevant from irrelevant information when solving a real-world problem. & 3.35 & 2.95 \\
\hline Use and apply relevant information to evaluate a problem. & 0.70 & 1.00 \\
\hline Use basic mathematical skills to help solve a real-world problem. & 0.80 & 0.85 \\
\hline Identify suitable solutions for a real-world problem using relevant information. & 1.05 & 1.35 \\
\hline Identify and explain the best solution for a real-world problem using relevant information. & 2.45 & 2.40 \\
\hline Explain how changes in a real-world problem situation might affect the solution. & 0.50 & 0.65 \\
\hline CAT Total Score & 16.85 & 17.32 \\
\hline$* p<.05 * * p<.01 * * * p<.001$ (2 -tailed) & & \\
\hline
\end{tabular}




\section{Discussion}

The evaluation results must be interpreted within the limitations and delimitations of the evaluation program. First, it is important to recognize that these results are specific to one institution's implementation of an undergraduate information systems capstone course. As clearly articulated earlier, there are many approaches to the capstone experience and we did not include all those dimensions within our course design. Second, we did not collect any demographic information from the participants in this course, which might have provided some context for the results of this evaluation. Third, some of these data are self-reported, which are subject to the honesty of the participants. It is possible that the participants supplied us with what could be considered socially acceptable responses. Fourth, some of the results provide inconsistent findings in that the CAT showed no significant gains in critical thinking whereas the results from the mini-cases suggest significant gains in several areas. Finally, we could only provide limited evidence of validity and reliability of the instruments used in this evaluation program. Notwithstanding these limitations and delimitations, we believe the results of our evaluation provide some useful insights.

The results from the student course evaluations (SAI) and the SALG show that most students that completed the course had a favorable perception about the course design. The average across all eight items on the student course evaluation was 4.51 on a five-point scale, which is a noticeable increase from the previous semester's average at 4.24. The student course evaluation, however, was largely focused on the student's perspective of the instructor. As we know, an instructor's teaching practice can largely influence student perceptions. Therefore, more data is necessary to gain a complete understanding of the student disposition, which is why the SALG is such a useful tool to evaluate the course. The SALG demonstrated that the students had more favorable views of the case pedagogy within the course as oppose to the final project and presentations. Further, students indicated that the case pedagogy helped them understand real-world issues $(M=4.77)$, and understand the relationships between concepts $(M=4.26)$. Also noteworthy is that students had high perceptions of the cases being written from local companies $(M=4.54)$ and the protagonists of the cases actually sitting in the course during discussion $(M=4.66)$.

The qualitative responses from the student course evaluations were generally positive, but some mixed and negative comments were made about the course design and instructor. One student brought up the alternative structure of the course: "Allowing the students to act out and show what they know versus lectures and exams made the class a great experience." Another student reinforced this view by saying, "Overall this was an interesting course. Some of the tools I learned will be put into action in my future job positions. This type of class structure should be in all business majors." However, some negative views were also observed, particularly about the case method and the final project presentations. One student said "the cases were too long and take a long time out of class to prepare." Another student commented about the presentations saying that "I did not enjoy the poster session. I did not like having to present 20 times. I would have rather presented once." We take these comments seriously and think that improvements to the course design can be made.

Perhaps the most troubling findings from our evaluation come from the actual student learning gains as measured by the CAT and the mini-cases. As a reminder, the CAT and mini-cases were administered both before and after the course so that we could examine change in student ability to evaluate information, think creatively, learn and problem-solve, and communicate effectively. Put simply, the two data sources show inconsistent findings. While the analysis of the mini-cases showed promise in students' ability to evaluate information, creative thinking, learning and problem-solving, and overall; the CAT results were stagnant and in some cases, diminished; except for a students' ability to summarize the pattern of results in a graph without making inappropriate inferences, which we think is a spurious finding. This inconsistency points to further research, particularly on the efficacy of case pedagogy in information systems classrooms. 
We think the final project distributions are indicative of the faculty in which the program resides. Some of our faculty members specialize in areas related to database design, data warehousing, and data mining. Most students pursued database projects and followed second by research projects. However, some decided to conduct comprehensive programming projects or website implementations, which involved real-world clients. What's more important about this particular facet of the evaluation is that both the students within the course and the instructor influenced the final grade on the project. Essentially, we were able to create a more authentic form of assessment based on peer-evaluation. Indeed, meta-analytic studies have verified the use of peer-evaluation closely resembles teacher assessment when judgments are made on well-understood criteria (Falchikov \& Goldfinch, 2000). We think that the use of peer-evaluation in information systems courses is a salient design feature that can be replicated across our programs and courses.

In summary, we believe we have provided a rich description of a novel information systems capstone course for undergraduate majors. We have reviewed several implementations of capstone courses offered at other intuitions of higher education and have identified common themes in these courses. Further, we have provided evidence of student learning gains and perceptions within this course based on a multi-method approach to evaluation. We believe this paper contributes to the body of knowledge in information systems education by providing several important considerations for information systems faculty members. In light of this objective, we provide some implications for practice in the subsequent section.

\section{Implications for Practice}

Though our implementation of the information systems capstone experience did not include all those possible dimensions (e.g., comprehensive team-based project), we do feel that we were successful in providing students an integrated and comprehensive experience. Information systems instructors must consider several important features of their capstone experience in light of how other courses are taught within the program. We were able to create a course design that emphasized the creation of a complex project, interaction with professionals in the field, and the effective integration of case pedagogy. Based on our experiences, we make the following recommendations to other faculty members in the field:

- We are advocates of the case method to stimulate fruitful dialog among students, encourage in-depth analysis and synthesis, and to build more integrated learning experiences for information systems students. Thus, we recommend that faculty adopt the case method in their instruction. This form of pedagogy requires a shift in perspective of faculty members from the sage-on-stage perpetuating traditional methods like lecture to more of a guide-on-the-side embracing interactive pedagogies (King, 1993). Opportunities are available to learn more about the case method (e.g., conferences) and to identify quality cases that can be used in the classroom.

- Using the case method in information systems curriculum requires quality cases be written on a variety of technical and managerial topics. Further, since technology changes so quickly, keeping these cases up-to-date is problematic. Therefore, we recommend that faculty share their teaching cases in a repository like the one supported by the Informing Science Institute. This practice not only provides a publication venue for faculty scholarship, but it also provides venue to gather quality instructional materials (cases) that can be seamlessly integrated into information systems courses.

- Providing flexibility in learning is an infrequently used design feature, but offers a lot of promise in that it gains buy-in from your learners. In this course, we essentially enabled the students to make the choices about the course policies via consensus through an online survey. Students made choices about the grading policy, the structure of the as- 
signments, the late work policy, and whether classes would be offered via online using a virtual classroom (we use Elluminate Live). We believe that giving students the choice to determine their own destiny gains buy-in and holds the students accountable to those policies later in the course. While this is one extreme, instructors might use some combination of this design strategy to meet the diverse need of their learners.

- The necessity for quality assessment in information systems is of paramount concern. In particular, there has been a call in our field for more alternative (a.k.a. authentic) methods of assessment as oppose to traditional methods (e.g., exams) which have been rightfully criticized for a lack of validity in measuring students' ability to apply knowledge to realworld situations (Wellington, Thomas, Powell, \& Clarke, 2002). Alternative methods of assessment attempt to overcome the limitation by developing authentic contexts in which students can demonstrate their mastery. A method often overlooked in the context of information systems includes the use of peer-evaluation as a mechanism to provide formative assessment to improve the quality of their peers' work, and provide a summative assessment of the work according to guidelines which meet course objectives. We encourage faculty to establish well-understood criteria to enable peer-evaluation within their courses.

- Speaking of alternative assessments, the use of ePortfolios is another option that offers several advantages over traditional methods. Though the use of ePortfolios was not emphasized in our course design, we believe the final projects reached the goal of representation, reflection, and revision - the essence of an ePortfolio initiative. Further, the final project was intended to be easily added to a student's ePortfolio. As we are still struggling with how to effectively evaluate our courses and programs, especially for accreditation purposes, we need to think about alternative forms of assessment that are authentic and strong indicators of quality. We believe that ePortfolios are a powerful way for faculty in information systems to accomplish these simultaneous goals. Our future course design will likely include an ePortfolio component.

- Information systems faculty should employ several methods to measure the outcomes of their courses, especially a capstone experience designed to be a culminating experience. Not only is this an expectation of accrediting agencies (e.g., ABET or AACSB), this is also an opportunity to help others in the field and conduct the scholarship of teaching and learning within our courses. The course design presented in this paper used a multimethod approach to document both student perceptions and student learning gains using both valid and reliable instruments. Similar approaches can be integrated into other courses seamlessly. Further, by doing so, faculty members can share their course design and evaluations in venues like the Journal of Information Technology in Education or the Journal of Information Systems Education.

- Information systems faculty should encourage intentional interactions between students and professionals in the field. In this course design, we invited the protagonists in the cases to class in which the students discussed the case studies in their presence. The protagonists were encouraged to engage in the conversation to make the experience more authentic for the students. Further, those students that achieved the highest scores on the final project had the opportunity to share their work with members of the advisory board for the department, a group of professionals throughout the region that the university serves. However, there are other ways to accomplish this goal. For instance, faculty members might invite recent graduates that are working in the field as guest speakers.

- Technology is not just a function of business today. We have widely adopted several emerging technologies in higher education to facilitate both face-to-face and online 
courses. One new strand that has emerged in recent years is the effectiveness of blended learning environments that fuse together both face-to-face and online components. We now have strong evidence that blended learning is perhaps the most effective model we have in higher education as evidenced by a Department of Education commissioned meta-analysis (Means, Toyama, Murphy, Bakia, \& Jones, 2010). Thus, we encourage faculty to thoughtfully integrate technology into the teaching and learning process (Learning Management Systems, Virtual Classrooms, etc.). As innovators and early adopters of technology (Rogers, 2003), we believe this integration process is feasible for our colleagues in a technology-centric field.

\section{Conclusions}

What can be concluded from this systematic evaluation of an information systems capstone experience for undergraduates? We believe our results suggest that the use of authentic case studies in information systems capstone courses for undergraduate students is an effective approach. We base this conclusion on the fact that the students had an overall high favorable perception the course design features and that the mini-cases demonstrated growth in critical areas. Though the use of the CAT did not demonstrate significant gains, we believe that one possible explanation for this is that the students were not graded on this activity and therefore perceived the activity to be a low-stakes assessment as oppose to a high-stakes assessment. We also believe that our paper presents the use of peer-evaluation as a viable alternative to traditional methods. We provided students the opportunity to evaluate their peers' work via well-established criteria. This approach can be easily and seamlessly integrated in other courses and programs.

This paper adds to a limited knowledge base about the efficacy of the case method in information systems education. Though the case method has existed for several decades, there is limited research on the effectiveness of this instructional method, particularly in information system education. We believe that the capstone course for the undergraduate information systems major is an appropriate venue for the case method. Further, we feel that this paper should serve as a catalyst for other information systems educators and researchers to innovatively study the case method within their own instructional practices.

\section{Acknowledgement}

This material is based in part upon work supported by the National Science Foundation under NSF Award 1043919. Any opinions, findings, and conclusions or recommendations expressed in this material are those of the authors and do not necessarily reflect the views of the National Science Foundation.

\section{References}

Astani, M. (2006). The MIS capstone course: An active learning approach. Issues in Information Systems, 7(1), 119-123.

Brandon, D., Pruett, J., \& Wade, J. (2002). Experiences in developing and implementing a capstone course in information technology management. Journal of Information Technology Education, 1(2), 91-102. Retrieved from http://www.jite.org/documents/Vol1/v1n2p091-102.pdf

Brumm, T. J., Ellertson, A., \& Mickelson, S. K. (2003). Using ePortfolios to develop and assess ABETaligned competencies. In Proceedings of the Annual Meeting of the American Society for Engineering Education, American Society for Engineering Education, Nashville, Tennessee (pp. 22-26).

Bryman, A. (2006). Integrating quantitative and qualitative research: How is it done? Qualitative Research, $6(1), 97-113$. 
Denton, J. W., \& Spangler, W. E. (2001). Effectiveness of an integrated pre-capstone project in learning information systems concepts. Journal of Information Systems Education, 12(3), 149-156.

Falchikov, N., \& Goldfinch, J. (2000).Student peer-evaluation in higher education: A meta-analysis comparing peer and teacher marks. Review of Educational Research, 70(3), 287-322.

FLAG. (2012). Field-Tested Learning Assessment Guide - Classroom Assessment Techniques: Student Assessment of Learning Gains (SALG). Retrieved from http://www.flaguide.org/cat/salg/salg1.php

Gill, T. G. (2010). Informing business: Research and education on a rugged landscape. Santa Rosa, CA: Informing Science Press.

Gill, T. G., \& Bhattacherjee, A. (2009). Whom are we informing? Issues and recommendations for MIS research from an informing sciences perspective. MIS Quarterly, 33(2), 217-235.

Gorgone, J. T., Davis, G. B., Valacich, J. S., Topi, H., Feinstein, D. L., \& Longenecker, H. E., Jr. (2003). IS 2002: Model curriculum and guidelines for undergraduate degree programs in information systems. Communications of the Association for Information Systems, 11(1), 1-63. Reprinted in Data Base, 34(1), iv-52.

Gupta, J. N. D., \& Wachter, R. M. (1998). A capstone course in information systems curriculum. International Journal of Information Management, 18(6), 427-441.

Harper, J. S., Lamb, S. W., \& Buffington, J. R. (2008). Effective use of case studies in the MIS capstone course through semi-formal collaborative teaching. Journal of Information Systems Education, 19(4), 411-418.

Hashemi, S., \& Kellersberger, G. (2009). The pedagogy of utilizing lengthy and multifaceted projects in capstone experiences. Information Systems Education Journal, 7(17), Available at: http://isedj.org/7/17/

HBS. (2013). Harvard Business School Case Method. Retrieved from http://www.hbs.edu/mba/academicexperience/Pages/the-hbs-case-method.aspx

Janicki, T. N., Fischetti, D., \& Burns, A. (2006). Incorporating real world projects and emerging technologies into one MIS capstone course. Information Systems Education Journal, 5(24). Available at: http://isedj.org/5/24/

King, A. (1993). From the sage on the stage to the guide on the side. College Teaching, 41, 30-35.

Kumar, A. (2006). Strategies to enhance student learning in a capstone MIS course. Issues in Informing Science and Information Technology, 3, 327-332.

McGann, S., \& Cahill, M. (2005). Pulling it all TOGETHER: An IS capstone course for the 21st Century emphasizing experiential and conceptual aspects, soft skills and career readings. Issues in Information Systems, 6(1), 1-7.

Means, B., Toyama, Y., Murphy, R., Bakia, M., \& Jones, K. (2010). Evaluation of evidence-based practices in online learning: A meta-analysis and review of online learning studies. United States Department of Education.

Morgan, R. E., \& Aitken, R. (2006). The business of information technology: An integrated, multidisciplinary approach to a capstone experience for management information sciences students. Information Systems Education Journal, 8(29). Available at: http://www.isedj.org/4/67/

Ritzhaupt, A. D., \& Gill, T. G. (2008). A hybrid and novel approach to teaching computer programming in MIS curriculum. In S. Negash, M. E. Whitman, A. B. Woszczynski, K. Hoganson, \& H. Mattord (Eds.), Handbook of distance learning for real-time and asynchronous information technology education (pp. 259-281). IGI Global.

Ritzhaupt, A. D., Singh, O., Seyferth, T., \& Dedrick, R. F. (2008). Development of the electronic portfolio student perspective instrument: An ePortfolio integration initiative. Journal of Computing in Higher Education, 19(2), 47-71. 
Rogers, E. M. (2003). Diffusion of innovations. Social Science.

Seymour, E., Weise, D. J., Hunter, A. B., \& Daffinrud, S. (2000). Using real-world questions to promote active learning. National Meeting of the American Chemical Society, San Francisco.

Schwieger, D., \& Surendran, K. (2010). Enhancing the value of the capstone experience course. Information Systems Education Journal, 8(29). Available at: http://isedj.org/8/29/

Shih, L. F., LeClair, J. A., \& Varden, S. A. (2010). The integrated technology assessment: A portfoliobased capstone experience. Information Systems Education Journal, 8(63). Available at: http://isedj.org/8/63/

Stein, B., Haynes, A., Redding, M., Ennis, T., \& Cecil, M. (2007). Assessing critical thinking in STEM and beyond. In M. Iskander, Innovations in e-learning, instruction technology, assessment, and engineering education (pp. 79-82). Springer Publishing.

Stein, B., Haynes, A., Redding, M., Harris, K., Tylka, M., \& Lisic, E. (2010). Faculty driven assessment of critical thinking: National dissemination of the CAT instrument. In K. Elleithy, T. Sobh, M. Iskander, V. Kapila, M. A. Karim, \& A. Mahmood, Technological Developments in Networking, Education and Automation (pp. 55-58). Springer Publishing.

Surendran, K., \& Schwieger, D. (2011). Incorporating capstone courses in programs based upon IS2010 Model Curriculum. Information Systems Education Journal, 9. Available at: http://isedj.org/20119/N2/ISEDJv9n2p65.html

Tuttle, S. M. (2000). A capstone course for a computer information systems major. ACM SIGCSE Bulletin, $32(1), 265-269$.

Tuttle, S. M. (2001). A capstone course for a computer information systems major. Journal of Computing Sciences in Colleges, 16(2), 41-48.

Wellington, P., Thomas, I., Powell, I. \& Clarke, B. (2002).Authentic assessment applied to engineering and business undergraduate consulting teams. International Journal of Engineering Education, 18(2), 168179. 


\section{Appendix: Mini-Case Example}

\section{Turnaround LLC}

Janet Washington was frustrated. In her role of CIO of Turnaround LLC, a medium-sized real estate company that specialized in turning around foreclosed properties, she had promised her boss Ellen - the company's CEO - that she would have a new application to manage the rapidly growing business in place by April. It was now June and, according to the project's lead developer, Fred, completion was still two weeks away. The problem was this: completion had been "two weeks" away for the last three months! What was she going to do?

\section{The Company}

Turnaround was a participant in the residential real estate industry. Its original principals were three real estate agents whose brokerage firms had gone out of business during the collapse in real estate that occurred within Florida starting in 2008. Rather than leave the business entirely, as many of the unemployed agents within the state had done, the trio had decided to get into the business of taking properties under the imminent threat of foreclosure and packaging them for rapid sales. Their business model was to work collaboratively with both owners and lenders to achieve a compromise that was beneficial to both and then to aggressively market the properties to buyers. The major source of the company's buyers was international investors and individuals seeking vacation properties. Boosted by a combination of rapidly dropping property values, low interest rates and a declining U.S. dollar, it was often possible for these customers to acquire properties at a $60 \%$ discount from what they would have paid in 2007 , at the peak of the Florida real estate bubble.

In the two years since the company's inception, it had grown from the three founders to over 100 employees. The key to success in the foreclosure industry was information. To put together a deal, Turnaround needed to be first to identify attractive properties that were likely to enter foreclosure. It then needed to contact the owners of the property to determine if they were amenable to working with Turnaround and also contact the lenders to determine if they would consider a short sale (i.e., a sale where the price paid for the property was less than the amount owed on the mortgage, meaning that the bank would need to write down its loan). Finally, the company had to determine whether or not the property was a match for any of the potential clients who had signed up for the service. When all three conditions were right, a deal could be structured. Typically, Turnaround received a $6 \%$ commission on any deal that closed, $2 \%$ paid by the seller, $2 \%$ by the purchaser and $2 \%$ by the lender. Such a commission structure was unusual in the industrywhere the seller was usually responsible for the entire commission-but it was attractive for all three parties in the event of the challenging type of sale that Turnaround usually put together.

By early 2011, the time of the case, Turnaround was brokering roughly 1400 properties a year, averaging $\$ 8000$ in commission from each transaction. The company had worked successfully with 11 different lenders and in six different Florida counties - a significant factor since rules for closing properties and responsibility for closing fees varied by county. To assist in the transaction volume, the company had acquired a title company in 2009 to help perform the closings. Generally speaking, Florida law, however, mandated that the purchaser have the right to choose its own title company to close a purchase sale. About $90 \%$ of purchasers chose to use the Turnaround affiliate title company. Those who chose to pick their own closing agent were required to pay a $\$ 500$ consulting fee to Turnaround. The purpose of this fee was to verify the quality of the closing documents, since errors in a near-foreclosure situation could be very costly. 


\section{The MIS Department}

Within a year of Turnaround's founding, the company was swamped in paperwork. Since none of its founders had an MIS background, all their processes had been manual. They did use the computer-e.g., to do their bookkeeping, to search county records for liens on properties (often a precursor to foreclosures), to perform credit checks on both buyers and sellers, and to perform online appraisals - but their use was task-driven, with no integrated workflow. In late 2008, the company hired Janet Washington, the MIS supervisor for a local mortgage broker that was cutting staff. She developed a series of spreadsheets to help keep track of business flows, set up a wireless network to handle the multiple workstations that were being added, installed a fax server and developed the company's web site. As the company grew, however, she found that she was spending nearly all her time training new hires on how to operate the various pieces of software used by the company and on keeping the system up and running.

By mid-2010, the company decided it needed a professional developer. Fred Eccles, a recent graduate of a local MS-MIS program, had applied for the job and everyone had been impressed by his "can do" attitude and his easygoing personality. His first month on the job, he successfully installed a Microsoft SharePoint server that was then used as a portal for document tracking and business process management. The installation was major success, allowing individual agents to identify and qualify potential buyers/sellers/properties $27 \%$ faster. Average turnaround time on each deal also declined from 11 weeks to 9 weeks. By December 2010, the installation was completed. By that time, Janet had another project in mind for him.

\section{The "Turnaround Central" Project}

The "Turnaround Central" project was originally based on something that Fred had read about on the Google site ${ }^{1}$. In November 2011, the company had introduced a product referred to as "Google Bust" that could be used to identify properties likely to enter foreclosure across the country. The product, currently in beta release (as was typical for Google), accessed county online records covering about $94 \%$ of the U.S. population ( $99 \%$ of Florida) and used a proprietary algorithm to assess the likelihood that they would enter foreclosure. More importantly, Google provided a free application program interface (API) that developers could embed into their code, making it possible to bring the data into the application, analyze it, then display it on a map (using another Google API for mapping). What Janet immediately perceived when Fred brought the API to her attention was that it could be the core of a new application that could be used to match client requests to suitable properties in real time. Fred further suggested that, using another API from Skype and an open source text-to-voice product, the product could be made to automatically call out to clients when a match appeared likely to determine if they were interested. In addition, he proposed that the system could be used to create and populate with data (e.g., property location, owner information, lender and mortgage facts) all the documents needed to initiate a workflow using SharePoint. This last activity alone, Janet estimated, could save the company up to 4 hours per property.

Fred, who had taken two programming courses as part of his undergraduate degree in MIS had suggested the program be developed using agile methods. Specifically, he planned to create a series of prototype applications with successively increasing functionality until a useful tool had been reached. From that point on, he planned to add features as needed. He was really excited about building the system and worked $12+$ hours per day over the holiday period to develop the first prototype, intended to demonstrate the interface. Janet and her boss, Ellen Sanchez, had been

1 Note: The "Google Bust" product described is fictional and is introduced solely for the purposes of the example case. 
so impressed that the two decided to hire another MIS employee so that Fred could complete the development as fast as possible.

In February 2011, Fred had demonstrated the system using test data - a little ahead of the informal schedule. At that time, Ellen had expressed her pleasure with how things were going. She had also suggested a few more features, ones that would be easy to implement (in Fred's opinion). Since bringing in real data seemed to be a largely mechanical activity-Fred had extensive database experience from three classes in his Master's program - he had estimated two weeks to completion. Since that time, however, the project had seemed to advance in fits and spurts. Certain features, such as the generation and loading of documents to SharePoint had been implemented rapidly. Other functionality, such as acquiring data from the Google API had caused problems from the very start - the amount of data was huge and the format in which it arrived seemed to vary from county to county. The potential customer database had been successfully imported from the spreadsheet where it was stored, but it was not clear how the system would be kept up-to-date.

\section{The Current Situation}

After hearing Fred's most recent two week estimate, Janet was very concerned. In anticipation of the productivity increases expected from the system, Turnaround had been very conservative in its hiring. As a result of the delays, however, average turnaround on a property had crept up to 12 weeks. This was serious, since part of the incentive for banks to work with Turnaround was to get delinquent properties off their books quickly. Moreover, the bad real estate market was not going to last forever. If they missed opportunities now, they might be gone forever.

Meanwhile, she could see that Fred realized the issue and was working like mad to try to get the project completed. And, to be sure, he was making progress. But was two weeks more work believable? Unfortunately, there was no documentation on the system-Fred ensured her the tools he was using were self-documenting - so she was having a very hard time getting a handle on what remained to be done.

\section{Questions}

Answer the two questions. Both explanations should refer to the facts as stated in the case.

1. What is your assessment of the "Turnaround Central" project and where it now stands?

2. If you were Janet Washington, what actions would you consider taking at this point and what do you think would be your best choice? 


\section{Biographies}

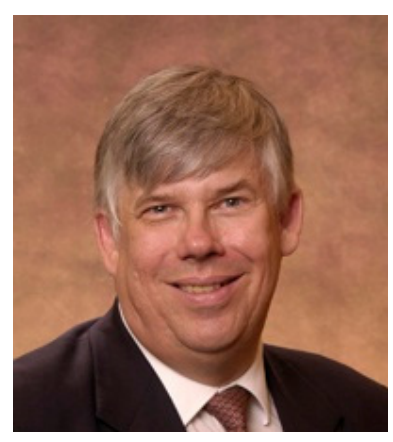

T. Grandon Gill is a Professor in the Information Systems and Decision Sciences department at the University of South Florida. He holds a doctorate in Management Information Systems from Harvard Business School, where he also received his M.B.A. His principal research areas are the impacts of complexity on decision-making and IS education, and he has published many articles describing how technologies and innovative pedagogies can be combined to increase the effectiveness of teaching across a broad range of IS topics. Currently, he is Editor-in-Chief of Informing Science: The International Journal of an Emerging Transdiscipline and an Editor of the Journal of Information Technology Education.

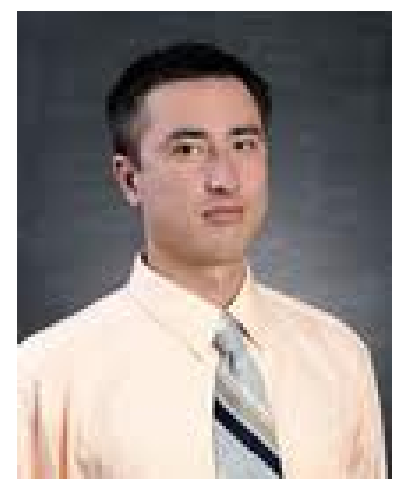

Albert D. Ritzhaupt is an assistant professor of educational technology in the School of Teaching and Learning at the University of Florida. His primary research areas focus on the design and development of technology-enhanced learning environments, computer and information systems education, and technology integration in education. His publications have appeared in multiple venues, including the Journal of Information Systems Education, Journal of Research on Technology in Education, Computers in the Schools, Journal of Computing in Higher Education, Computers \& Education, Behavior Research Methods, Journal of Interactive Learning Research, Journal of Computers in Mathematics and Science Teaching, Journal of Educational Computing Research, and Computers in Human Behavior. 